\title{
HOST SUITABILITY OF SOME EUCALYPTS FOR DEVELOPMENT OF THE EUCALYPTUS LEAFROLLER (STREPSICRATES MACROPETANA)
}

\author{
N.A. MAUCHLINE ${ }^{1}$, T.M. WITHERS ${ }^{2}$ and Q. WANG $^{1}$ \\ ${ }^{1}$ Plant Protection Group, Massey University, Private Bag 11222, Palmerston \\ North \\ ${ }^{2}$ Forest Health, Forest Research, PB 3020, Rotorua \\ Corresponding author: toni.withers@forestresearch.co.nz
}

\begin{abstract}
Strepsicrates macropetana (Lepidoptera: Tortricidae) is a pest occurring only on species of Eucalyptus. No-choice trials were carried out by inoculating eggs onto potted plants of E. nitens, E. saligna, E. fastigata and $E$. regnans held in a glasshouse. A number of development parameters, including pupal weight, time to adult eclosion and survival from egg to adult, were measured. All hosts were suitable for complete development of larvae, however mean survival to adult was highest on E. fastigata (61\%). The shortest time to eclosion (40 days) occurred on E. nitens. There was no difference in pupal weight between host species. Adult female fecundity was variable. The results indicate that the species of Eucalyptus tested, which were from subgenera containing economically important species, all supported development of $S$. macropetana.

Keywords: Strepsicrates macropetana, Tortricidae, Eucalyptus, host range, development.
\end{abstract}

\section{INTRODUCTION}

The eucalyptus leafroller (Strepsicrates macropetana (Meyrick), Lepidoptera: Tortricidae) was first recorded in Auckland in 1923 (Dugdale 1988). It is a pest of eucalypts in both Australia and New Zealand, although it has a higher pest status in New Zealand (Elliott \& deLittle 1985). The larvae feed on shoot tips, buds and young leaves within a shelter formed from silken threads (Nuttall 1983). The pest can be responsible for severe deformation of the growing tips of many susceptible species of eucalypts (Mauchline et al. 1999), particularly in nurseries and newly planted plantations. The impact that this insect can have on eucalypt growth and form led us to investigate the host range, and in particular, the effect of different host species in different sub-genera of the vast genus Eucalyptus on insect development.

\section{Database searches}

\section{MATERIALS AND METHODS}

Host plant records were compiled from the Forest Health database (Forest Research, Rotorua), authors' unpublished records, specimen labels in the National Forest Insect Collection (FRNZ), the New Zealand Arthropod Collection (NZAC) and the Australian National Insect Collection (ANIC).

No-choice development trials

No-choice trials were performed to determine whether different Eucalyptus species influence the life history of eucalyptus leafroller. Four species were chosen as representatives of the major sections or subgenera of Eucalyptus containing economically important plantation species. The classification followed is that of Brooker (2000). The species were E. fastigata and E. regnans (section Eucalyptus), E. nitens (section Maidenaria) and E. saligna (section Latoangulatae). Trees were obtained from nurseries in 1998 and 1999 and were maintained 
within a glasshouse at the Massey University Plant Growth Unit. The experiment was a randomised block design, split by time (two cages for each of the four species per block in two separate replicates in July and September 1999). A total of two trees of each species were used per cage (a cylindrical curtain hang net $1500 \mathrm{~mm}$ height $\mathrm{x} 100 \mathrm{~mm}$ diameter). The hang nets were stabilised by wire hoops and suspended from an overhead wire. Each tree was inoculated with fifteen eggs ( $\mathrm{n}=30$ eggs per cage) which were obtained from a laboratory colony of the eucalyptus leafroller that was reared on E. macarthurii foliage at $20^{\circ} \mathrm{C}$ and 16:8 h light:dark. Plants were checked every second day and larvae that had pupated were collected and weighed with an electronic balance (Mettler AE100, Watson Victor Ltd, NZ), sexed and held until eclosion. Mating pairs were individually placed into plastic containers $(100 \times 85 \mathrm{~mm})$ containing a paper towel on which eggs could be laid. Adult moths were given access to 5\% sucrose solution through an inverted test tube stopped with a $25 \mathrm{~mm}$ dental cotton wick. The total number of eggs laid were counted then held in Petri dishes until hatching to measure egg viability. Measures of survival from egg to adult, mean pupal weight and mean time from egg to adult eclosion per cage were analysed as a factorial design blocked by time, using a Generalised Linear Model procedure (Minitab for Windows version 13). When host plant effects existed, means were separated with a Tukey test.

\section{Database searches}

\section{RESULTS}

The eucalyptus leafroller has been recorded from 37 different host species in New Zealand and an additional 4 in Australia (Table 1). All are from Eucalyptus spp. All the major subgenera of Eucalyptus present in New Zealand are represented in the host list. No-choice development trials

Eucalyptus leafroller mean development time to adult eclosion was significantly influenced by host species $(\mathrm{P}<0.05)$. There was no significant block, cage or interaction effect. Development was significantly faster on $E$. nitens in both replicates than on E. fastigata or E. regnans, by a mean of two days, but was not faster than on E. saligna (Table 2 ). Pupal weight was not significantly influenced by host species $(\mathrm{P}>0.05)$, nor was there any block or cage effect (Table 2). Mean survival from egg inoculation to adult eclosion was significantly influenced by host species $(\mathrm{P}<0.01)$, as well as cage $(\mathrm{P}<0.01)$ and block $(\mathrm{P}<0.05)$. This result is because of unexpectedly low survival of larvae on one replicate on E. saligna. Overall, survival to adult was highest on E. fastigata (Table 2) and lowest on E. saligna. Across all host species, only $50 \%$ of mating pairs successfully laid eggs. Of these, the mean number of eggs laid per female ranged between 75 and 100. Furthermore, the proportion of these eggs laid per female that were fertile was also very variable, ranging between $0 \%$ and $100 \%$

\section{DISCUSSION}

There were only small differences in development of eucalyptus leafroller reared on two different subgenera of Eucalyptus. Each of the species tested could support the development of eucalyptus leafroller larvae. The average pupal weight was not influenced by host species, but survival to adult and development time were affected. Survival from egg to adult was highest on E. fastigata and lowest on E. saligna. The extent to which survival from egg inoculation to adult eclosion in this laboratory trial reflects survival on different host species in the field is unclear. Average pupal weight and development time may be better indicators of host suitability in the eucalyptus leafroller. Development time was fastest on E. nitens by between one and two days. These differences are not large in relation to the biology of the insect (Mauchline et al. 1999). The variability in number and viability of eggs laid by the adult females may have been due to unsatisfactory matings in the laboratory, a factor that may be quite different in a field situation.

Furthermore, the searches of databases in New Zealand indicate that species of Eucalyptus from virtually all the different subgenera and sections are utilised as hosts in 
TABLE 1: Available records on the host range of $S$. macropetana.

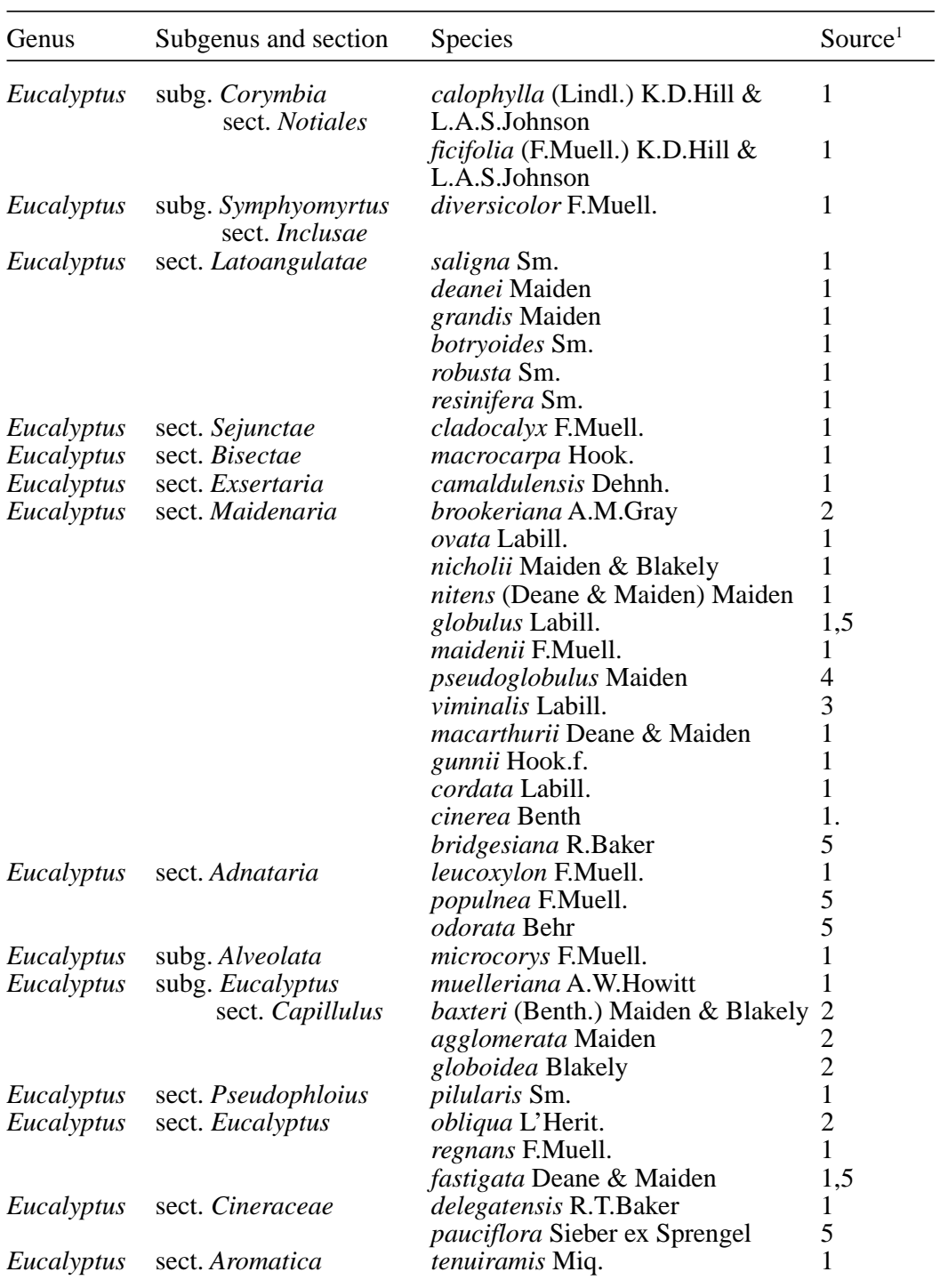

${ }^{1} 1$ =FH Database, $2=$ =Authors' records, 3=FRNZ, 4=NZAC, 5=ANIC.

this country from time to time. Little additional information is available on the range of hosts utilised by the eucalyptus leafroller in its native range in Australia. Majer et al. (1997) suggested that species within the subgenus Eucalyptus (previously referred to as Monocalyptus by Pryor \& Johnson (1971)) are less susceptible to insect attack than 
TABLE 2: The mean ( \pm SE) pupal weight, days to adult eclosion and survival of Strepsicrates macropetana per cage when reared on different Eucalyptus hosts. Means followed by the same letter in a row are not significantly different at $\mathrm{P}<0.05$.

\begin{tabular}{|c|c|c|c|c|}
\hline & \multirow{2}{*}{\multicolumn{2}{|c|}{$\begin{array}{c}\text { subg. Eucalyptus } \\
\text { sect. } \\
\text { Eucalyptus }\end{array}$}} & \multicolumn{2}{|c|}{ subg. Symphyomyrtus } \\
\hline & & & \multirow{2}{*}{$\begin{array}{l}\text { sect. } \\
\text { Maidenaria } \\
\text { E. nitens }\end{array}$} & \multirow{2}{*}{$\begin{array}{l}\text { sect. } \\
\text { Latoangulatae } \\
\text { E. saligna }\end{array}$} \\
\hline & E. fastigata & E. regnans & & \\
\hline No. of pupae & 72 & 63 & 58 & 41 \\
\hline $\begin{array}{l}\text { Mean pupal } \\
\text { weight (mg) }\end{array}$ & $14 \pm 0.8$ & $16 \pm 0.7$ & $16 \pm 0.4$ & $16 \pm 0.6$ \\
\hline $\begin{array}{l}\text { Mean days to } \\
\text { adult eclosion }\end{array}$ & $42 \pm 0.8 \mathrm{a}$ & $42 \pm 0.3 \mathrm{a}$ & $40 \pm 0.06 \mathrm{~b}$ & $41 \pm 0.3 \mathrm{ab}$ \\
\hline $\begin{array}{l}\text { Mean \% survival } \\
\text { to adult eclosion }\end{array}$ & $60.8 \pm 4.6 \mathrm{a}$ & $53.3 \pm 7.2 b$ & $49.2 \pm 3.2 \mathrm{~b}$ & $35.0 \pm 3.5 \mathrm{c}$ \\
\hline
\end{tabular}

species within the subgenus Symphyomyrtus. This hypothesis is not supported by our data on the host range of the eucalyptus leafroller.

This research has confirmed that the eucalyptus leafroller is restricted to species of Eucalyptus. No section of the genus Eucalyptus represented in New Zealand showed any significant resistance or tolerance to attack from larvae. This conclusion is further backed up by the finding that female eucalyptus leafroller readily accepted the same four eucalypt species for oviposition, although within a laboratory assay, E. regnans was preferred (N. Mauchline, unpubl. data). We conclude that eucalyptus leafroller is probably a serious threat to all chemically unprotected eucalypt nursery stock and young trees planted out in the field in New Zealand. Further research into control methods is justified.

\section{ACKNOWLEDGMENTS}

Thanks to Robert Hoare, Landcare Research, John Dugdale, Nelson, and Martin Steinbauer, CSIRO, for access to records; to colleagues for their helpful refereeing of this manuscript; and to Ray Johnson, Massey University, for use of facilities.

\section{REFERENCES CITED}

Brooker, M.I.H. 2000: A new classification of the genus Eucalyptus L'Hér. (Myrtaceae). Aust. Systematic Bot. 13: 79-148.

Dugdale, J.S. 1988: Lepidoptera- annotated catalogue, and keys to family-group taxa. Science Information Publishing Centre, DSIR, Wellington, New Zealand. 262 p.

Elliott, H.J.; deLittle, D.W. 1985: Insect pests of trees and timber in Tasmania. Forestry Commission, Tasmania, Hobart. 90 p.

Majer, J.D.; Recher, H.F.; Wellington, A.B.; Woinarski, J.C.Z.; Yen, A.L. 1997: Invertebrates of eucalypt formations. In: Williams, J.E.; Woinarski, J.C.Z. ed. Eucalypt ecology. Individuals to ecosystems. Cambridge University Press, Cambridge. Pp. 278-302.

Mauchline, N.A.; Withers, T.M.; Wang, Q.; Davis, L. 1999: Life history and abundance of the eucalyptus leafroller (Strepsicrates macropetana). Proc. 52nd N.Z. Plant Prot. Conf:: 108-112.

Nuttall, M.J. 1983: Spilonota macropetana Meyrick (Lepidoptera: Tortricidae). Forest and Timber Insects in New Zealand No. 57. Forest Research Institute and New Zealand Forest Service, Rotorua. $4 \mathrm{p}$

Pryor, L.D.; Johnson, L.A.S. 1971: A classification of the eucalypts. The Australian National University, Canberra. 102 p. 